\title{
The Impact of Roman Roads and Milestones on the Landscape of the Iberian Peninsula
}

\author{
Camilla Campedelli
}

Werner Eck octuagenario

For the Romans, it was all but necessary to know the physical space and the territory they occupied or which they hoped to dominate, in order to overcome the obstacles posed by distance from the center of power to the periphery. Having detailed knowledge of the territory and the people would be a perquisite for establishing an efficient Roman administration. ${ }^{1}$ The use of pre-existing routes and the opening of new roads at first allowed the movement of soldiers and consequently the conquest and organisation of a territory that, over the centuries, came to reach an area of 6 million $\mathrm{km}^{2}$ and was connected through a road network which expanded to $120,000 \mathrm{~km} .^{2}$ The munitio of roads by the pavement of some of their segments and the erection of inscribed milestones, a Roman peculiarity in the Ancient World, enabled communication within the confines of the empire and equipped the Iberian landscape with the 'Roman characteristics'.

The concept of landscape is a fluid one. Especially research of the last century was polarised between mainly humanistic approaches, linked to historicalcultural, aesthetic and perceptual aspects on the one side, and scientific ones, grounded in geography and ecology, on the other. More recently, studies started to integrate the multiple existing approaches. ${ }^{3}$ This is evident in the

1 C. Nicolet, L'Inventaire du Monde. Géographie et politique aux origines de l'Empire romain (Paris 1988), 9.

2 R. Chevallier, Les voies romaines (Paris 1998), 306.

3 M.G. Gibelli, 'Paesaggio e paesaggi: tante definizioni per una sola parola. Landscape and landscapes: one word, a lot of meanings', in C. Teofili and R. Clarino (eds.), Riconquistare il paesaggio. La Convenzione Europea del Paesaggio e la Conservazione della Biodiversità in Italia (Rome 2008), 108-123, part. 109-113; B. David and J. Thomas, 'Landscape archaeology: introduction', in B. David and J. Thomas (eds.), Handbook of Landscape Archaeology (London 
definition of landscape contained in the "European Landscape Convention" of October 20, 2020: "Landscape' is an area, as perceived by people, whose character is the result of the action and interaction of natural and/or human factors." ${ }^{4}$

So far, studies dedicated to Roman roads have mainly focused on the archaeological, historical-administrative and economic aspects. ${ }^{5}$ Much rarer are the works dedicated to the relationship between roads and landscape. Among these, one of N. Purcell's papers of 1990 is pivotal, in which he analysed the development of the concepts of geography and "social landscape" in the period from the second Punic war to Claudius in Cisalpine Gaul. He stressed the fundamental role of tracing roads (particularly the via Flaminia, Aemilia and Postumia) and centuriation as instrumental in both the generation of knowledge of space as well as in the creation of a Roman landscape. ${ }^{6}$ With a different approach to the subject, but likewise an eye-opener, the anthology "Via per montes excisa. Strade in galleria e passaggi sotterranei nell'Italia romana" examines concrete examples of massive Roman interventions on the ecotope of the Italian peninsula and, in less detail, of the provinces. ${ }^{7}$ R.E. Witcher published a most interesting analysis of the Roman road system within the context of social landscapes based on three case studies of the via Amerina in the lands of the ager Faliscus, the Gallia Cisalpina and Colchester (Essex), taking into consideration the Roman respect (or lack thereof) for the nature of the territory, the use of pre-existing routes, and contemporary constructions. He concludes that the landscape with roads and milestones is an "expression and manifestation of the ideology of the Roman rule." ${ }^{8}$ The most recent reflections by A. Kolb, as well as my own, on the road system and on milestones as a medium of self-representation of power argue along the same lines. ${ }^{9}$

and New York 2008), 27-43; A. Leone, Riflessioni sul paesaggio (Rome 2009), 9-14. See the contributions of Günther Schörner and Marietta Horster in the present volume on terminology and concepts within a variety of antiquity-related disciplines.

4 European Landscape Convention 1,1a, see https://www.coe.int/en/web/landscape (last accessed on March 23, 2021).

5 A. Kolb, 'Via ducta - Roman road building: An introduction to its significance, the sources and the state of research', in A. Kolb (ed.), Roman Roads. New Evidence - New Perspectives (Berlin and Boston 2019), 13-17.

6 N. Purcell, 'The creation of provincial landscape: The Roman impact on Cisalpine Gaul', in T. Blagg and M. Millett (eds.), The Early Roman Empire in the West (Oxford 1990), 7-29.

7 M.S. Busana (ed.), Via per montes excisa. Strade in galleria e passaggi sotterranei nell'Italia romana (Rome 1997).

8 R.E. Witcher, 'Roman roads: Phenomenological perspectives on roads in the landscape', in C. Forcey, J. Hawthorne and R. Witcher (eds.), TRAC97. Proceedings of the Seventh Annual Theoretical Roman Archaeology Conference (Oxford 1998), 6o-70.

9 A. Kolb, 'Raumwahrnehmung und Raumerschliessung durch römische Strassen', in M. Rathmann (ed.), Geographie und Raumwahrnehmung in der Antike (Mainz 2007), 169-180; 
Hence, the present work is rooted in this kind of studies which analyse the impact of Rome on the physical landscape and the political and social value of this transformation, and therewith taking into account as well the bipolar definition of landscape contained in the European Landscape Convention. Not all the road axes of the peninsula, however, will be taken into consideration, but only the most important for traffic and transport. In the future, the topic will hopefully be considered in greater depth and expanded to the whole peninsula and to other provinces of the Roman Empire. Additionally, it will hopefully serve as a starting point for the study of landscape in later periods as in the case of the recent work of J.E. Albone, who in his PhD thesis "Roman Roads in the Changing Landscape of Eastern England c. AD 410-1850" analysed the influence of the Roman road network on the development of the landscape in Eastern England after 410 CE. ${ }^{10}$

In this paper, three aspects will especially be taken into account. Firstly, I will consider the impact of streets on the varied physical landscape of the Iberian peninsula, and more specifically, cases in which road constructions have been adapted to the physical landscape. Furthermore, I will examine cases in which the physical landscape has been modified to build roads. Next I will consider the impact on the physical landscape by the monumentalisation of roads through milestones, bridges and arches. At the end of this analysis, I will aim at highlighting some socio-political aspects which accompanied these infrastructure projects, and therefore, the creation of a Roman landscape in the Iberian peninsula through the construction of roads and the positioning of the milestones.

\section{The Impact of Streets on the Varied Physical Landscape of the Iberian Peninsula}

Roman Hispania, then as today, represents a territory dominated in the centre by an immense plateau, the Meseta Central, mountain ranges such as the Pyrenees, the Cantabrian Mountains or Picos de Europa, the Central System, the Iberian System, and the Sierra Moraine (Cordillera Bética), and few rivers, except for the southern region around the Guadalquivir. The Greek geographer

C. Campedelli, 'Viae publicae als Mittel der Vermessung, Erfassung und Wahrnehmung von Räumen: Das Beispiel der Provinz Hispania Citerior Tarraconensis (CIL XVII/1)', in W. Eck et al. (eds.), Öffentlichkeit - Monument - Text. XIV Congressus Internationalis Epigraphiae Graecae et Latinae 27.-31. Augusti MMXII. Akten (Berlin 2014), 608-610.

10 The thesis is available online: https://ueaeprints.uea.ac.uk/id/eprint/63543/1/Albone _Roman_Roads_in_the_Changing_Landscape.pdf (last accessed on April 21, 2020). 
Strabo (64/63 BCE-c. 24 CE), in the third book of his Geographia, describes the Iberian peninsula with these words:

Now of Iberia the larger part affords but poor means of livelihood; for most of the inhabited country consists of mountains, forests, and plains whose soil is thin - and even that not uniformly well-watered. Northern Iberia, in addition to its ruggedness, not only is extremely cold, but lies next to the Ocean, and thus has acquired its characteristic of inhospitality and aversion to intercourse with other countries; consequently, it is an exceedingly wretched place to live in. Such, then, is the character of the northern parts; but almost the whole of Southern Iberia is fertile, particularly the region outside the Pillars. ${ }^{11}$

In this geographical context the Roman road network developed along four main axes (s. map 6.1): First, the via Augusta that ran along the Mediterranean coast and the bank of the Baetis river up to the Atlantic Ocean;12 second, the via Augusta which from Tarragona led to the north-western coast; ${ }^{13}$ third, the via which, crossing the Meseta Central, connected Caesaraugusta with the province of Lusitania; ${ }^{14}$ and fourth, the so-called 'via de la Plata', which connected the province of Baetica and the region of Callaecia through the province of Lusitania. ${ }^{15}$ These axes, with some changes which will also be discussed shortly, are attested since prehistoric times. The Phoenician-Carthaginian colonisation of the southern part of the peninsula caused a further development of settlements and consequently of the road network. ${ }^{16}$ Of particular interest is the concentration of roads and milestones in the inaccessible north-western region

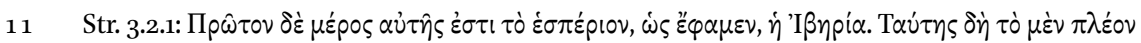

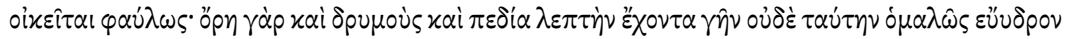

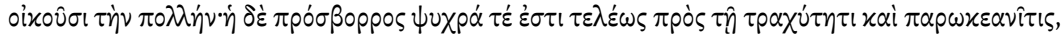

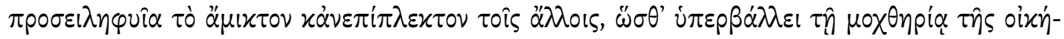

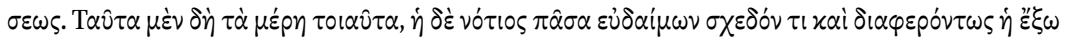
$\sigma \tau \eta \lambda \hat{\omega} \nu$. (transl. by H.L. Jones 1923). CIL XVII/1, p. 1-2 for the section from the Pyrenees to Castulo; P. Sillières, Les voies de communication de l'Hispanie méridionale (Paris 1990), part. 291-328 for the following section to Cádiz.

13 CIL XVII $/ 1$, p. 83-85.

14 CIL XVII/1, p. 189-19o.

15 J.M. Roldán Hervás, Iter ab Emerita Asturicam: El Camino de la Plata (Salamanca 1971).

16 J.Ma. Blázquez Martínez, 'De la antigüedad a la Hispania romana', in J.A. Abásolo (ed.), Viaje por la historia de nuestros caminos (Madrid 1997), 10-13; M. Almagro Gorbea, 'Las vías de comunicación en la Prehistoria', in M. Criado de Val (ed.), Atlas de caminería hispánica.1 Vol I: Caminería peninsulary del Mediterráneo (Madrid 2011), 20-25. 


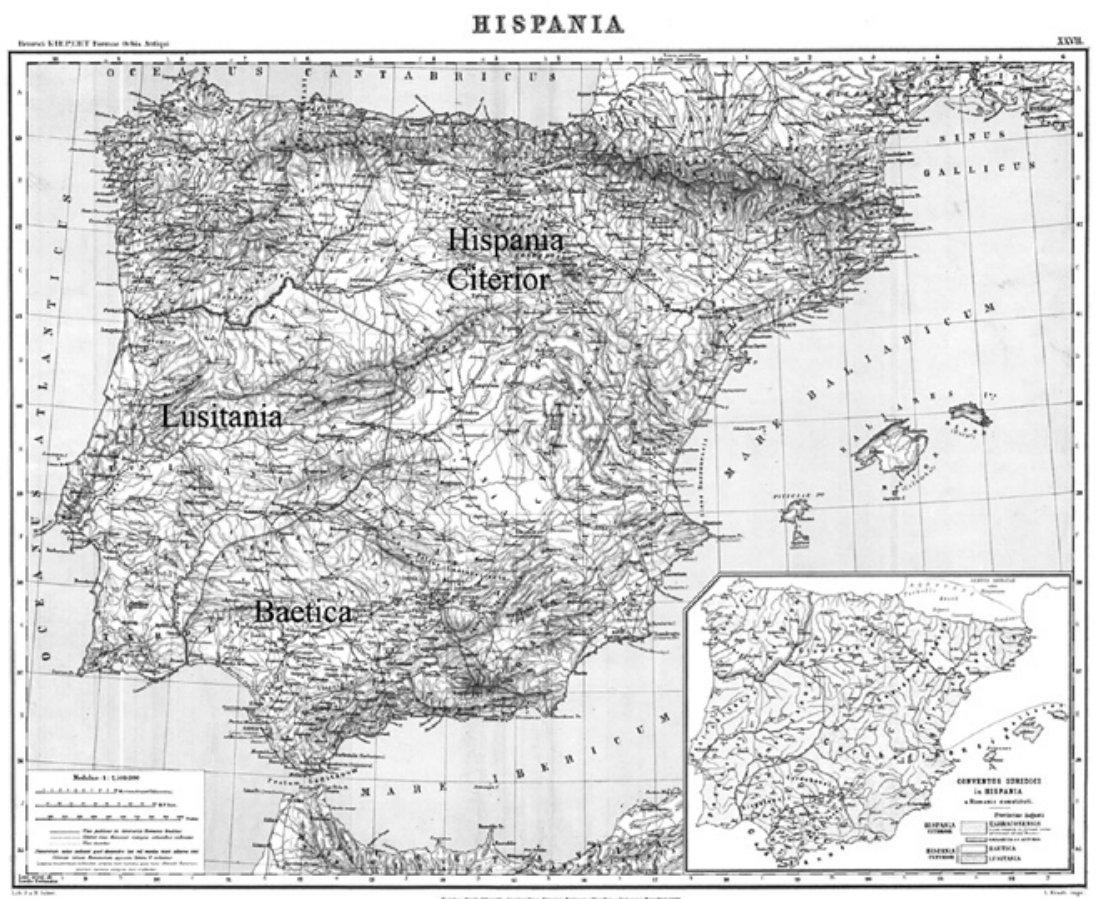

MAP 6.1 The main roads of Roman Hispania: H. Kiepert, Formae orbis antiqui, 27 Hispania, Berlin 1893

of Hispania citerior Tarraconensis, namely in the praefecturae of Asturiae and et Callaecia. ${ }^{17}$

\subsection{Cases in Which Road Constructions Have Been Adapted to the Physical Landscape}

The above listed four axes were essentially laid out in accordance with the topographical characteristics of the territory. The via Augusta, which ran along the Mediterranean coast and the bank of the Baetis river, was the longest in the whole peninsula. It started from Summus Pyrenaeus (Le Perthus), passed through Tarraco, Carthago Nova, and Castulo to reach the province of Baetica and thence the ocean (s. map 6.2)..$^{18}$ This road was travelled by Hannibal and the Scipiones at the time of the Second Punic War, as well as later by Caesar

17 A. Rodríguez Colmenero, S. Ferrer Sierra and R.D. Álvarez Asorey, Miliarios e outras inscricións viarias romanas do Noroeste hispánico (conventos bracarense, lucense e asturicense) (Santiago de Compostela 2004).

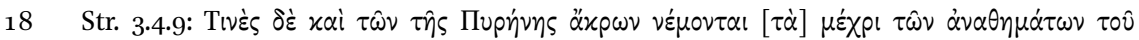

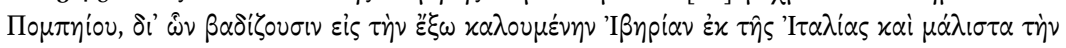

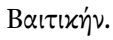




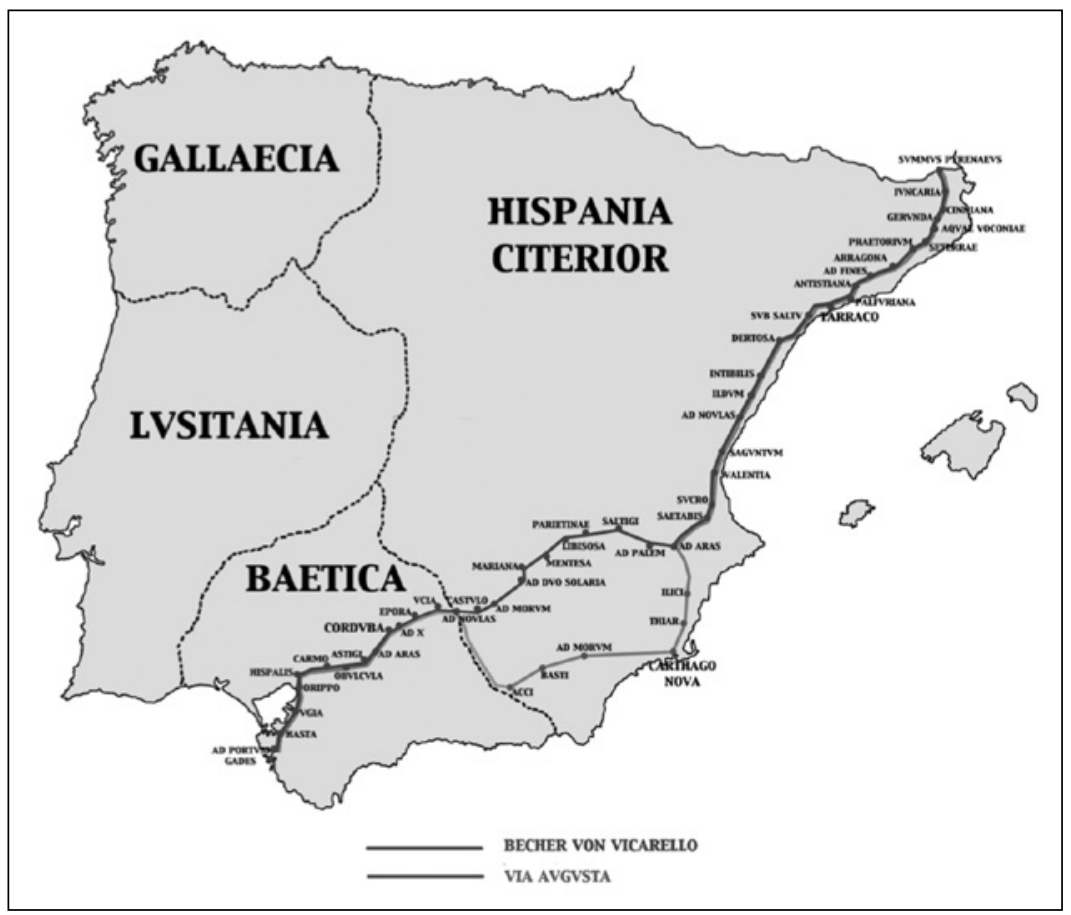

MAP 6.2 The via Augusta

COURTESY M.G. SCHMIDT

to reach Obulco in view of the battle of Munda..$^{19}$ Polybius specifies that the Romans measured this road by placing a column (a milestone) every eight stadia (i.e. every mile), ${ }^{20}$ while Strabo informs his readers: "This road sometimes approaches the sea, though sometimes it stands off at a distance from the sea, and particularly in the regions on the west."21 The discovery of a series of milestones and the sequence of mansiones indicated in the itineraria (Barcino-Ad Fines - Antistiana-Palfuriana-Tarraco) confirm that the road had its starting point at the coast near Barcino (today Barcelona) heading inland (s. map 6.3). ${ }^{22}$ Taking this way, not touching the Catalan Coastal Range its course followed the left bank of the Rubricatum river (Llobregat). The road passed Ad Fines, a settlement attested by a mansio, including an ancient bridge, an Augustan arch

19 Liv. 21.23.1-6; 24.41.5-11; 28, 13, 4; Plb. 3.39; Str. 3,4,9.

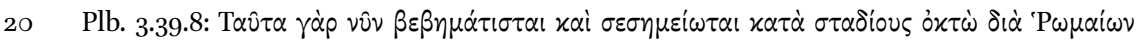

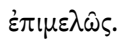

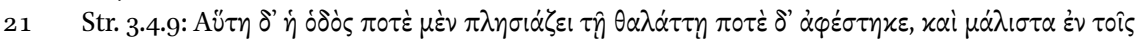

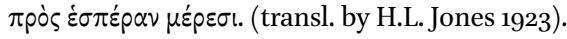




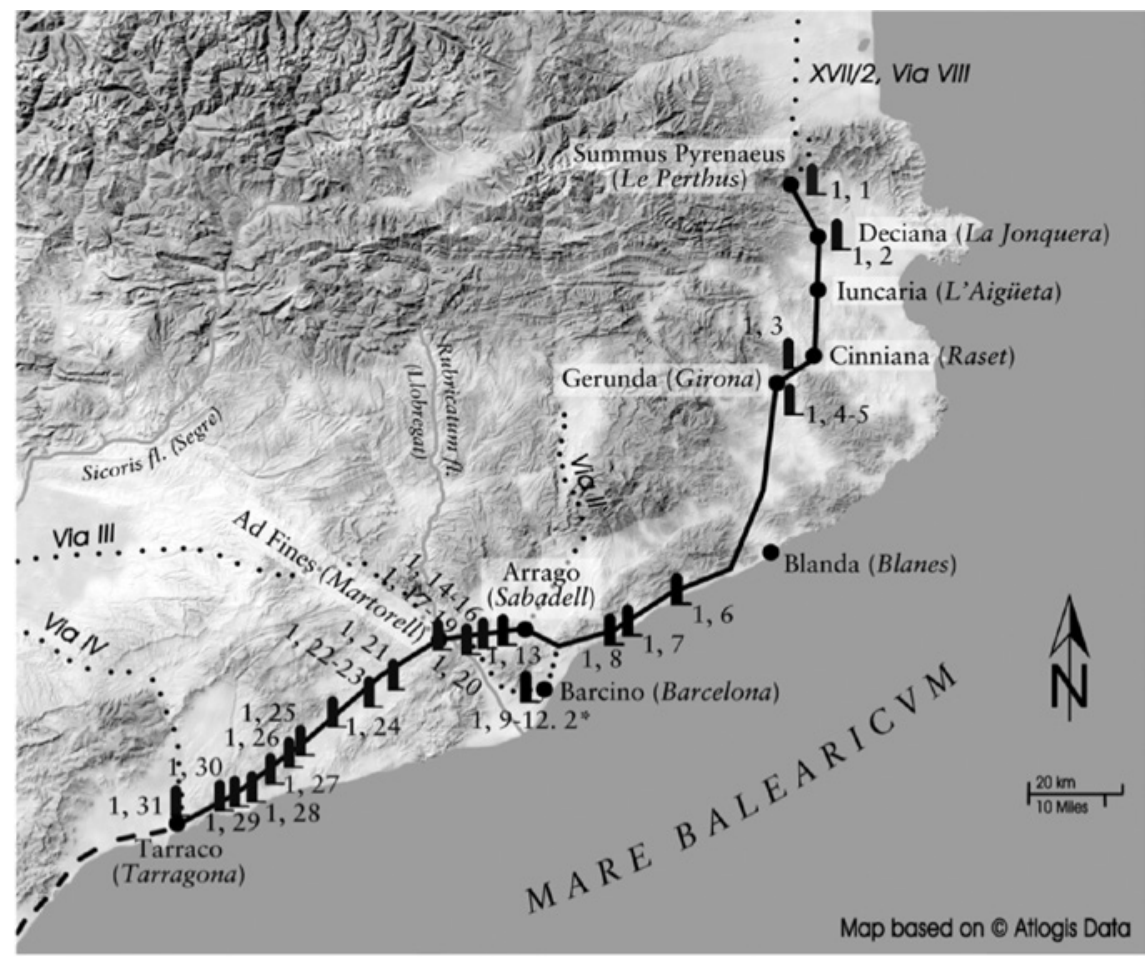

MAP 6.3 The via Augusta from Summus Pirenaeus to Tarraco COPYRIGHT CORPUS INSCRIPTIONUM LATINARUM (CIL XVII/1)

spanning the cobblestones of a Roman road that leads across the Rubricatum river. ${ }^{23}$ These monuments indicate the importance of this traffic junction from which two republican routes depart: the road that reached Auso (Vic) and the one that connected Barcino with Caesaraugusta passing through Ilerda (s. map 6.4). ${ }^{24}$ Once in Tarraco, the via Augusta - says Strabo - "runs towards the passage of the Iberus at the city of Dertossa." ${ }^{25}$ The mountainous nature of the region south of the Hiberus river once again forced the route to Saguntum to deviate away from the coast, as attested by several milestones dating from the first to third centuries CE (s. map 6.5). ${ }^{26}$

\footnotetext{
23 Cf. $C I L$ XVII $/ 1$, p. 1.

24 Cf. $C I L$ XVII/1, p. 66, 76.

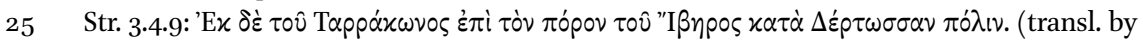
H.L. Jones 1923).

$26 \quad C I L$ XVII $/ 1$, p. 38-61.
} 


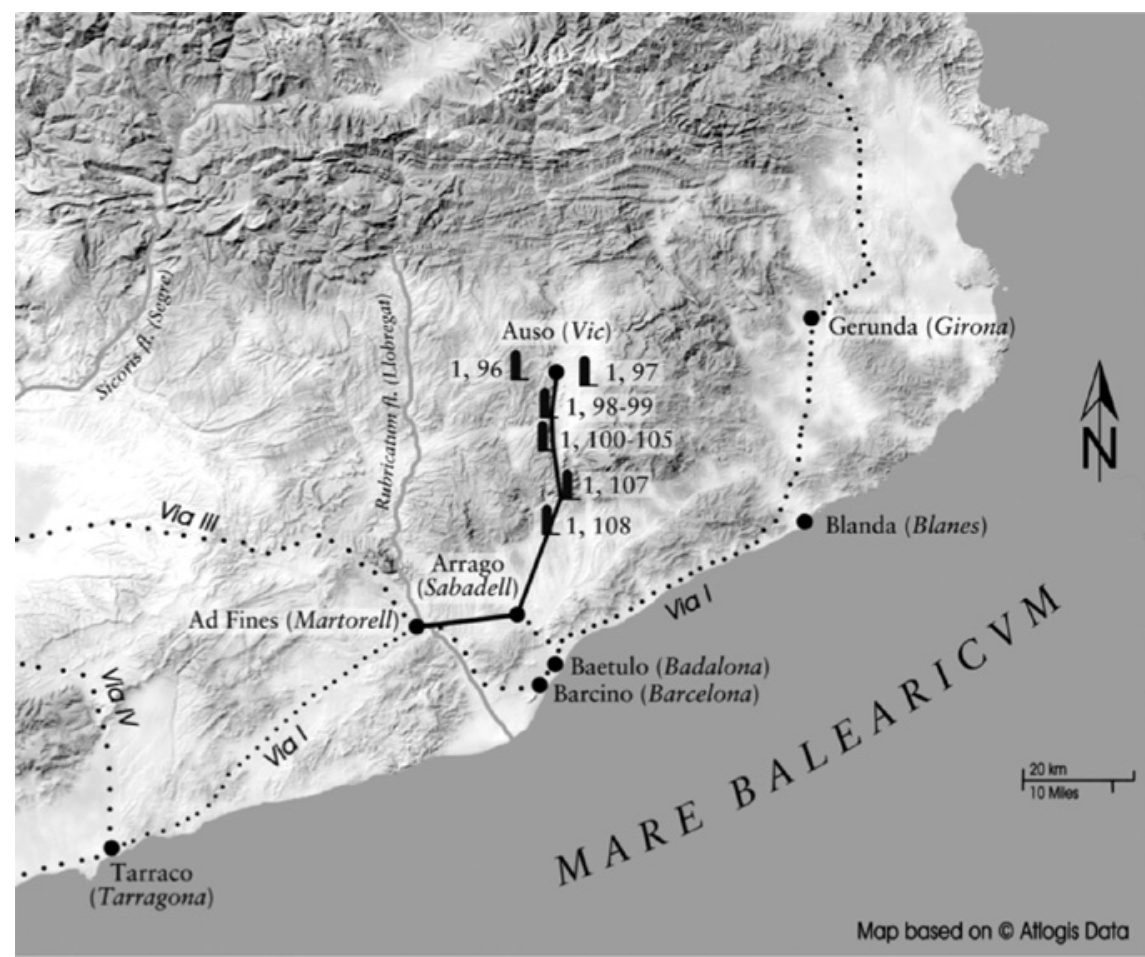

MAP 6.4 Roman roads around Ad Fines

COPYRIGHT CORPUS INSCRIPTIONUM LATINARUM (CIL XVII/1)

Strabo continues: "After passing through Saguntum and the city of Saetabis, it gradually departs from the sea and joins what is called the Spartarian - or as we should say, the 'Rush' Plain. This plain is large and has no water but produces the kind of broom that is suitable for twisting into ropes, and is therefore exported to all regions, particularly to Italy. Now formerly the road must have passed through the centre of this plain and through Egelasta". In this passage, Strabo refers to the so-called 'Camino de Haníbal', attested by the four Vicarello goblets, which crossed the peninsula along a central axis (s. map 6.2). ${ }^{27}$ "At the present day, however, they have made it run toward the coastal regions, merely touching upon the Rush Plain, yet leading to the same place as the former road did, namely to the regions around Castulo and Obulco."28 It is likely

27 CIL XI $3281-3284$ on which see most recently M.G. Schmidt, 'A Gadibus Romam. Myth and reality of an ancient route', BICS 54 (2011), 71-86.

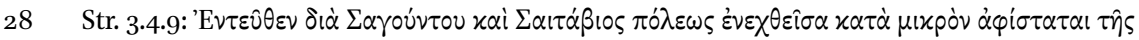

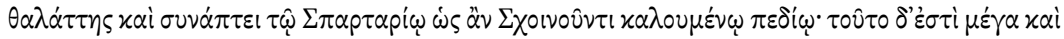




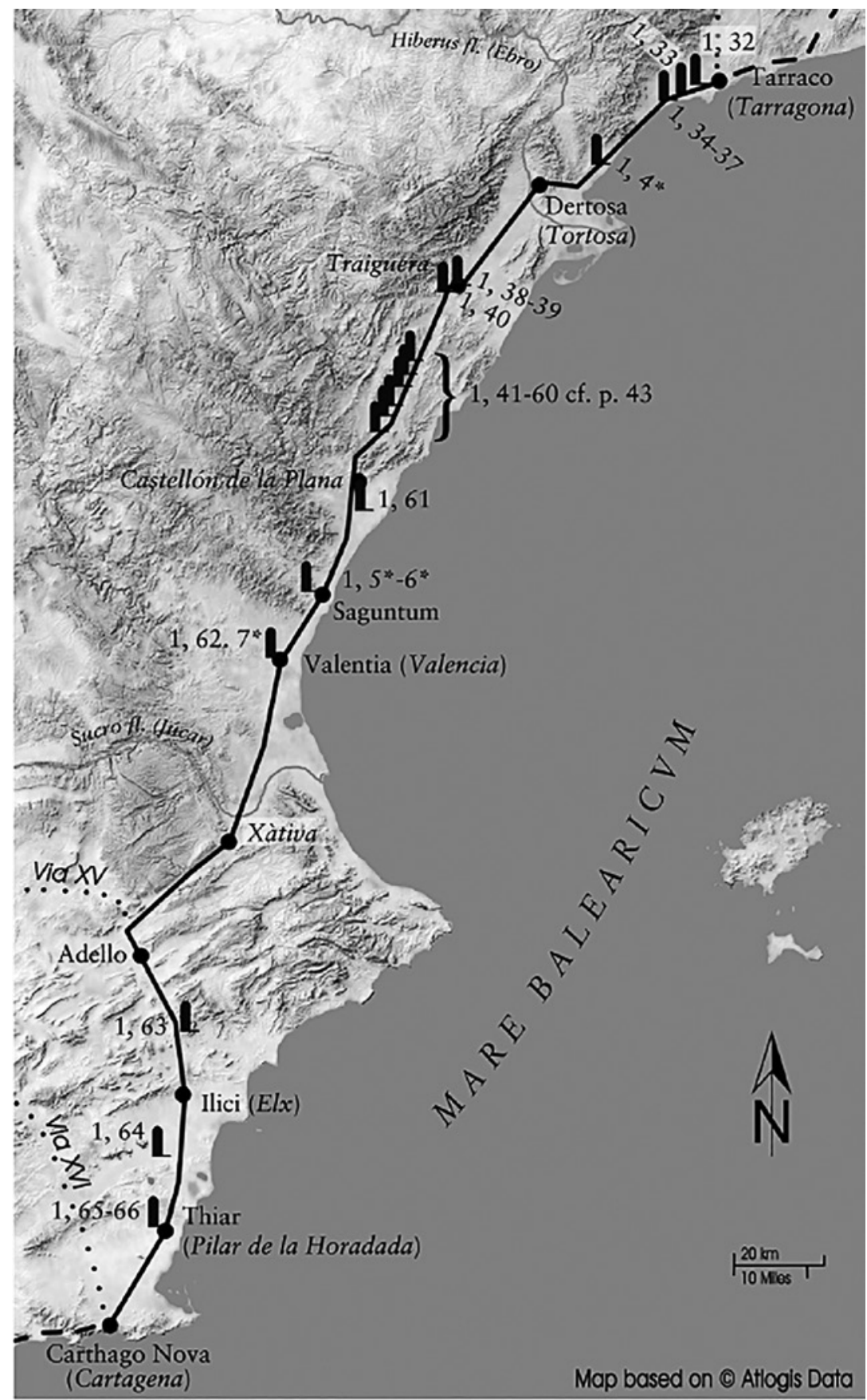

MAP 6.5 The via Augusta from Tarraco to Carthago Nova COPYRIGHT CORPUS INSCRIPTIONUM LATINARUM (CIL XVII/1) 
that the route of the road had been modified by the Romans to avoid the dangerous saltus Castulonensis (i.e. the eastern part of the Sierra Morena), which, as Cicero recalls, was at that time (i.e., in 43 BCE) "full of robbers". ${ }^{29}$ The older 'Herculean' diagonal was no longer an accessible traffic connection through the interior of the country - this would have been the case for some individual sections at most - but rather a mythical route and a survey line at the same time, i.e. a direttissima covering the entire length of the Iberian peninsula. ${ }^{30}$ The Augustan infrastructure policy aimed at creating modern routes that would enable frequent connection with faster shipping traffic, at least for the sections which ran along the coast, as some milestones attest. ${ }^{31}$

The saltus Castulonensis is an important 'landmark'. From the beginnings of the Roman conquest it had a special strategic importance because of its significance as a passage point between the Levant and the valley of the Guadalquivir through the region of La Mancha, as well as for its copious mineral resources. ${ }^{32}$ An inscription attests the reconstruction of a road by a procurator of Augustus; the saltus Castulonensis is explicitly indicated: viam quae per Castul(onensem) / saltum Sisaponem ducit / adsiduis imbribus corrup/tam munivit. ${ }^{33}$

The area east of Castulo is of particular interest because here, at the Baetis (ad Baetem), was located the caput viae arcus Augusti, which also marked the beginning of the province of Baetica (unde incipit Baetica), as witnessed by seven milestones and roadwork inscriptions dating from Augustus to Vespasian. ${ }^{34}$ After

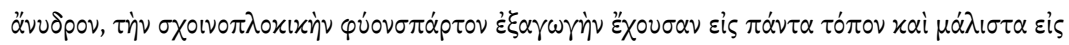

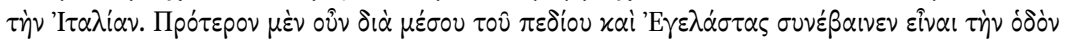

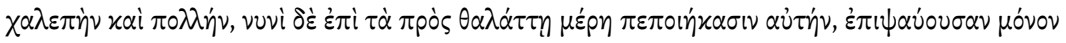

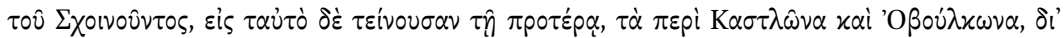

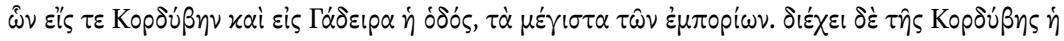

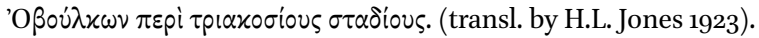

29 Cic. Fam. 10.31.1: Minime mirum tibi debet videri nihil me scripsisse de re publica postea quam itum est ad arma. nam saltus Castulonensis, qui semper tenuit nostros tabellarios, etsi nunc frequentioribus latrociniis infestior factus est, tamen nequaquam tanta in mora est quanta qui locis omnibus dispositi ab utraque parte scrutantur tabellarios et retinent.

$30 \quad$ Schmidt 2011, op. cit. (n. 27).

$31 \quad C I L \mathrm{XVII} / 1$, p. $62-66$.

32 Cf. Liv. 22.20.12; 27.20.3.

33 CIL II $3270=$ ILS 5513 (Linares/Castulo): Q(uinto) Torio Q(uinti) f(ilio) Culleoni / proc(uratori)Aug(usti) provinc(iae)Baet(icae)/ quod muros vetustate / collapsos d(e)s(ua) p(ecunia) refecit solum / ad balineum aedificandum / dedit viam quae per Castul(onensem / saltum Sisaponem ducit / adsiduis imbribus corrup/tam munivit signa Vene/ris Genitricis et Cupidi/nis ad theatrum posuit / HS centies quae illi summa / publice debebatur addito / etiam epulo populo remisit / municipes Castulonenses / editis per biduum circens(ibus) / $d($ ecreto $) d($ ecurionum $)$.

CIL II 4709-4712, 4715, 4679 (=ILS 5867), 4721. 


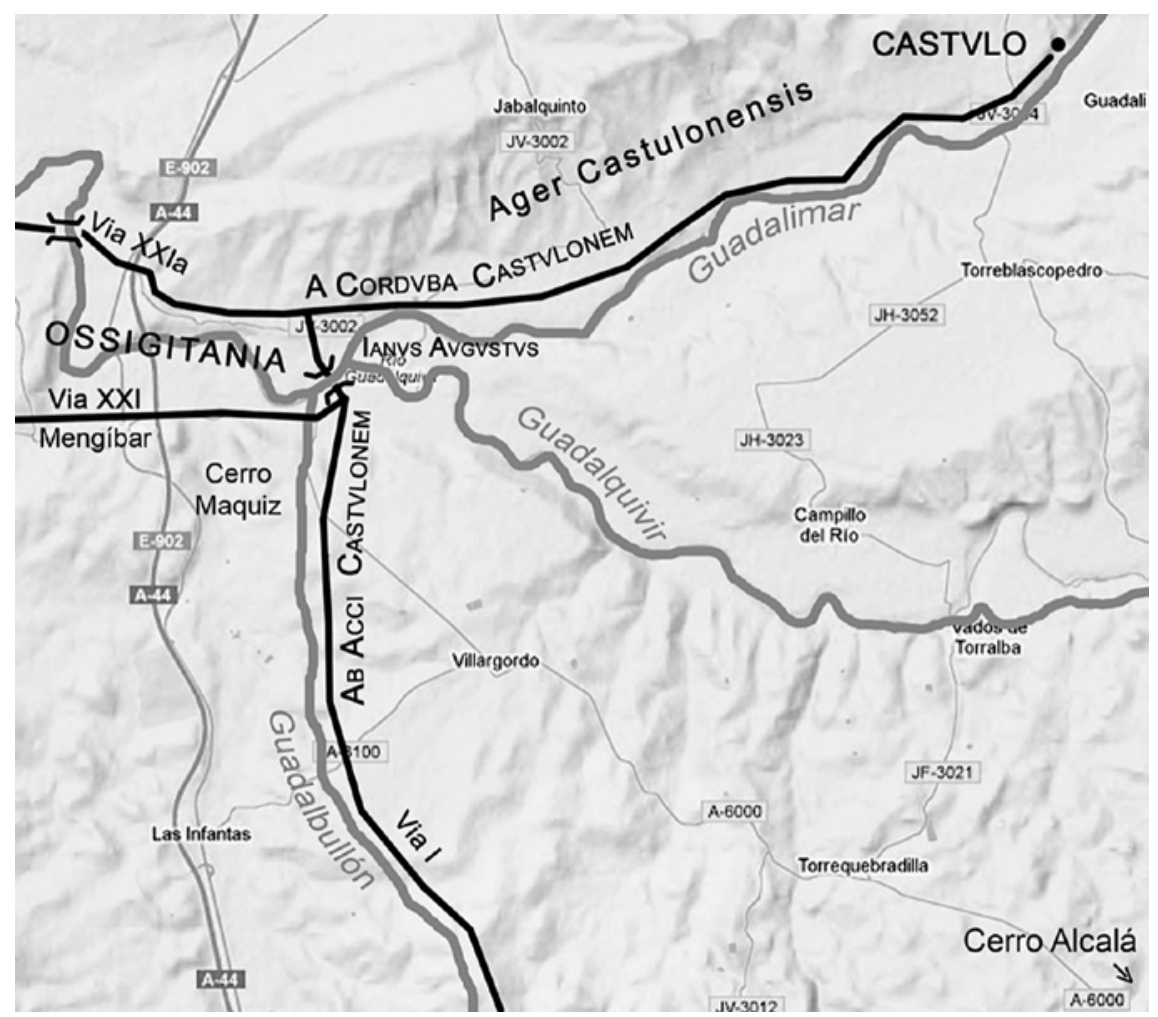

MAP 6.6 The localization of the arcus Augusti COURTESY M.G. SCHMIDT

centuries of debate on the location of the arcus Augusti, Manfred G. Schmidt, taking into account for the first time an Arabic itinerarium of the tenth century, has convincingly demonstrated that it was located at the intersection of two rivers, the Guadalquivir and the Guadalbullón (the border between Hispania Citerior and Ulterior), and two roads (s. map 6.6): the new section of the via Augusta, which ran right along the Guadalbullón, and the oldest 'Camino de Haníbal'. ${ }^{35}$ The importance given to the natural elements of the territory, that is to say to the landscape, is evident: the rivers, together with the roads, constitute a real 'landmark' from which the miles of the road were counted and the provincia populi Romani began.

35 M.G. Schmidt, 'Ab Iano Augusto ad Oceanum. Methodologische Überlegungen zur Erforschung der viae publicae in der Baetica', in I. Czeguhn et al., (eds.), Wasser - Wege Wissen auf der iberischen Halbinsel. Eine interdisziplinäre Annäherung im Verlauf der Geschichte (Baden-Baden 2018), 35-53. 
Based on the sources available, we can deduct that the most important route of the Iberian peninsula, which connected Baetica to Italy and had certainly already been outlined before Roman times, was not particularly changed under their rule. The natural landscape did not undergo massive interventions but assumed the appearance of a Roman landscape due to the presence of milestones, bridges and arches. Furthermore, its Roman character was defined through the measurement of the roads on the basis of the Roman mile and the erection of milestones. The Iberian landscape was rationalised by the rulers as well as users of the routes.

\subsection{Cases in Which the Physical Landscape Has Been Modified to Accommodate the Construction of Roads}

In the southern regions of the Iberian Peninsula, we can still see the solutions adopted by Roman builders in the development and implementation of the road system in a morphologically intricate territorial context. There are numerous routes in the mountains and in the plains where the solution adopted was the 'cut road' or the road in the trench. The most frequent formula consisted of the combination between terracing and cutting, while the trench was generally used when the way passed a hill which was deemed necessary to regularise to reduce the difference in height. Among the most interesting examples are those belonging to the previously mentioned 'Camino de Haníbal' which, at Corral Rubio, has a $4 \mathrm{~m}$ deep section of trench. $5 \mathrm{~m}$ deep is the trench at Los Navas de San Juan. The via Augusta, at its entrance into the Betica, resorted to a 6-8 $\mathrm{m}$ deep cut to climb the steep left bank of the Guadalquivir. Near Espeluy, the road crossed a natural saddle with a trench section of $5^{-6} \mathrm{~m}$. Even the route Corduba-Augusta Emerita found its path among the rocks in several areas, for example in the ascent of Cerro Muriano: at the Loma de Los Escalones, the cut was up to $100 \mathrm{~m}$ long, with an average width of $3 \mathrm{~m}$. On the road from Italica to Augusta Emerita (the so-called 'Vía de la Plata'), the route used cuts and terraces north of Torremejía after crossing the Arroyo del Quico. There are also examples from the minor axes: the long ramp 3.6o-3.80 m wide and $2-3.40 \mathrm{~m}$ deep at the foot of the oppidum of Ladera de Morana, perhaps a section in the trench at the eastern exit from Urso on the road Malaca-Corduba and, on the Urso-Ostippo section of the road Malaca-Italica. ${ }^{36}$

36 A. Coralini, 'Complanatis montibus et caesis rupibus ... Vie in galleria, in tagliata e in trincea nel mondo romano e al di fuori dell'Italia peninsulare', in M.S. Busana (ed.), Via per montes excisa. Strade in galleria e passaggi sotterranei nell'Italia romana (Rome 1997), 309-311. Cf. Sillières 199o, op. cit. (n. 12), 267-268, 270, 300, 301, 404, 409, 416, 419. 
The north-eastern border of the Iberian Peninsula consists of the Pyrenees. In the ancient literature, this mountain range is often compared to the Alps for its high peaks, gullies, and snows. The poet and orator Florus, e.g., in his dialogue written under Hadrian, Vergilius orator an poeta, says upon arriving in the Pyrenees: [...] flecto cursum, sed statim par horrore, par vertice, par ille nivibus Alpinis excepit. ${ }^{37}$ Strabo, describing the western passage, notes that at the time of the Roman conquest: "[...] only with difficulty could they [the Romans] get supplies out of Aquitania on account of the rough roads."38

There were three bigger Pyrenean passages, one to the west (Alto de Ibañeta, Roncesvalles), one to the east (Le Perthus), and one in between (Puerto de Somport). The second, the one described by Florus, connected the peninsula with Gallia Narbonensis and with Italy; the others led to Aquitania. It is obvious that in this morphological context, even though passes and valleys were present in large quantities according to Strabo, ${ }^{39}$ it would sometimes have been necessary to modify the physical conformation of the territory.

From Caesaraugusta (Zaragoza), a road reached the town of Tarraga (Sádaba), headed north towards the valley of las Cinco Villas, Sos del Rey Católico and then eastwards following the river Aragón and the lake Embalse de Yesa until it reached the Pyrenees and the westernmost central passage Summus Pirenaeus near today's Puerto de Somport. ${ }^{40}$ This route, indicated by numerous milestones dating between the third and fourth centuries, is referred to by an inscription found in Siresa (Hecho, $\mathrm{HU}){ }^{41}$ The text of the epigraph reads:

Iussu domini et principis nostri / Magni Maximi victo[ris] / semper Augusti (vac.?) / Antonius Maximinu[s v(ir) c(larissimus)], / nova[e] provinciae Ma $[$ ximae $]$ / primus consularis e $[$ t antea $]$ / praeses, viam adfa $[$ tim $] /$ rupibus famosam, ia [m hiem]/alibus aquis perviam [a fundo] / conplanavi (!), solo paca[to et] / perdomito averso [flumine] / inundationes obit [er coercui?]. ${ }^{42}$

37 Flor. Verg. 2.3. Cf. S. Rocchi, P. Annio Floro, Virgilio: oratore o poeta? Introduzione, testo critico, traduzione e commento (Berlin and Boston 2020), 95-96.

38 Str. 3.4.18. (transl. by H.L. Jones 1923).

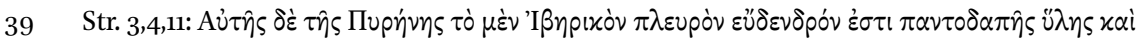

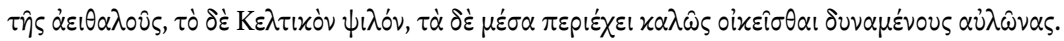
On the route and the milestone of Somport see: L. Pros, 'El miliario del Somport y la vía Caesaraugusta - Beneharno', El nuevo miliario 2 (2006), 24-27; I. Moreno Gallo, Item a Caesarea Augusta Beneharno. La carretera romana de Zaragoza al Béarn (Zaragoza 2009). CIL XVII/1, p. 101-102, 118 and n. 1, 162-184. $C I L$ II $4911=\mathrm{XVII} / 1.1,185$. 
The mention of the Emperor Magnus Maximus suggests a plausible dating of the monument and works project at some point between 383 and 388 . The gouverneur of the province nova Maxima (most likely the Tarraconensis) says (1. 7-12) that he let do some essential works on the road. ${ }^{43}$ The road in question ran along the previously carved cliff of the mountain and a river. Frequent landslides and floods forced the governor to level the road's surface by lowering it on one side and raising it on the other, in order to divert the course of the river so that it could still flow along the road.

So far, in the cases analyzed here, it is clear that Roman interventions in the environment for the sake of constructing roads were not particularly profound and, in terms of technical commitment and scope of the results, no works are comparable to those of Italy and Gallia. ${ }^{44}$

\section{The Impact on Landscape by the Monumentalisation of Roads through Milestones}

Streets with milestones, bridges, and arches were some of the most evident symbols of the Roman presence in the territory and, as we have already seen, clear attributes of a 'Roman landscape'. With the following words - a locus classicus - Plutarch describes, in the vita Gaii Gracchi, his road construction measures during the last third of the second century BCE:

But he busied himself most earnestly with the construction of roads, laying stress upon utility, as well as upon that which conduced to grace and beauty. For his roads were carried straight through the country without deviation, and had pavements of quarried stone, and substructures of tight-rammed masses of sand. Depressions were filled up, all intersecting torrents or ravines were bridged over, and both sides of the roads were of equal and corresponding height, so that the work had everywhere an even and beautiful appearance. In addition to all this, he measured off every road by miles (the Roman mile falls a little short of eight furlongs) and planted stone pillars in the ground to mark the distances. Other stones, too, he placed at smaller intervals from one another on both sides of the road, in order that equestrians might be able to mount their horses from them and have no need of assistance. ${ }^{45}$

\footnotetext{
$43 \quad$ CIL XVII /1, p. 185. (Germ. transl. by M.G. Schmidt).

44 Coralini 1997, op. cit. (n. 36), 309.

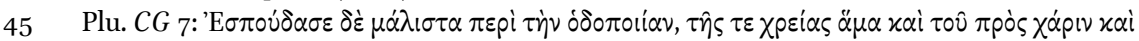

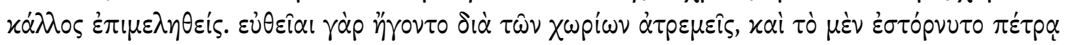


It is not known whether Plutarch's description represents a realistic or merely an idealised image of the Roman roads in his time but we can assume that it came close to the contemporary reality. In the Iberian Peninsula, roads with similar characteristics were built from the Augustan period onwards. In republican times, milestones on the Iberian Peninsula were few and small. After Augustus had conquered the whole peninsula, an expansive road system was built, equipped with monumental milestones (approx. $3 \mathrm{~m}$ ), which connected the most important cities of the peninsula (fig. 6.1). ${ }^{46}$ Mention has already been made of the monumentalisation of traffic junctions at Ad Fines and at the arcus Augusti. Among the examples worthy of note is certainly the arch of Titulcia, at the crossroad of the streets Augusta Emerita-Caesarauguta and Asturica Augusta-Laminium (Itin. Anton. 435, 4-5; 436, 1; 438, 8; 439, 11). ${ }^{47}$

Of particular interest is the north-western region of the Iberian Peninsula, coinciding with the praefecturae of Asturia and Callaecia in the Hispania citerior Tarraconensis, a mountainous territory inhabited by rebellious peoples. ${ }^{48}$ Although of little strategic value, the region maintained a vital importance due to its mineral resources. ${ }^{49}$ This geographic area presents a varied morphology, which leads from the dilated plains of Castilla y León to those irrigated by the Duero, Esla and Órbigo rivers, to mention the main beds. The imposing mountainous bastions that surround the lowland to the north and to the west separate it at the same time from the coastal edge. Nonetheless the traffic from the meseta to the interior and coastal lands travelled along natural passages known since prehistoric times. ${ }^{50}$

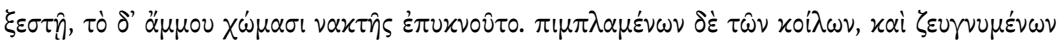

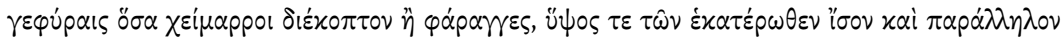

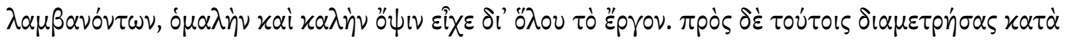

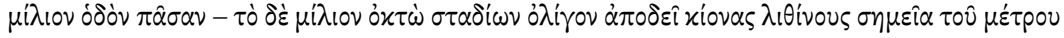

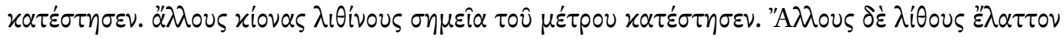

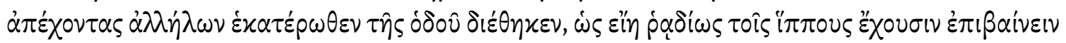

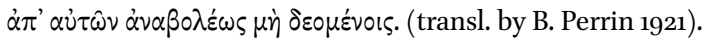

46 Cf. C. Campedelli, 'Von der römischen Besitzergreifung zur Verwaltung der Iberischen Halbinsel - das Zeugnis der Meilensteine', in O. Dally et al. (eds.), Politische Räume in vormodernen Gesellschaften Gestaltung - Wahrnehmung - Funktion, Internationale Tagung des DAI und des DFG-Exzellenzclusters TOPOI vom 18.-22. November 2009 in Berlin (Leidorf 2012), 87-93.

$47 \quad C I L \mathrm{II}^{2} / 13,1$.

48 Cf. $A E$ 2000, 760.

49 Cf. C. Domergue, Les mines de la Péninsule Ibérique dans l'antiquité romaine (Rome 1990), part. 40-44.

50 Rodríguez Colmenero et al. 2004, op. cit. (n. 17), 12. 


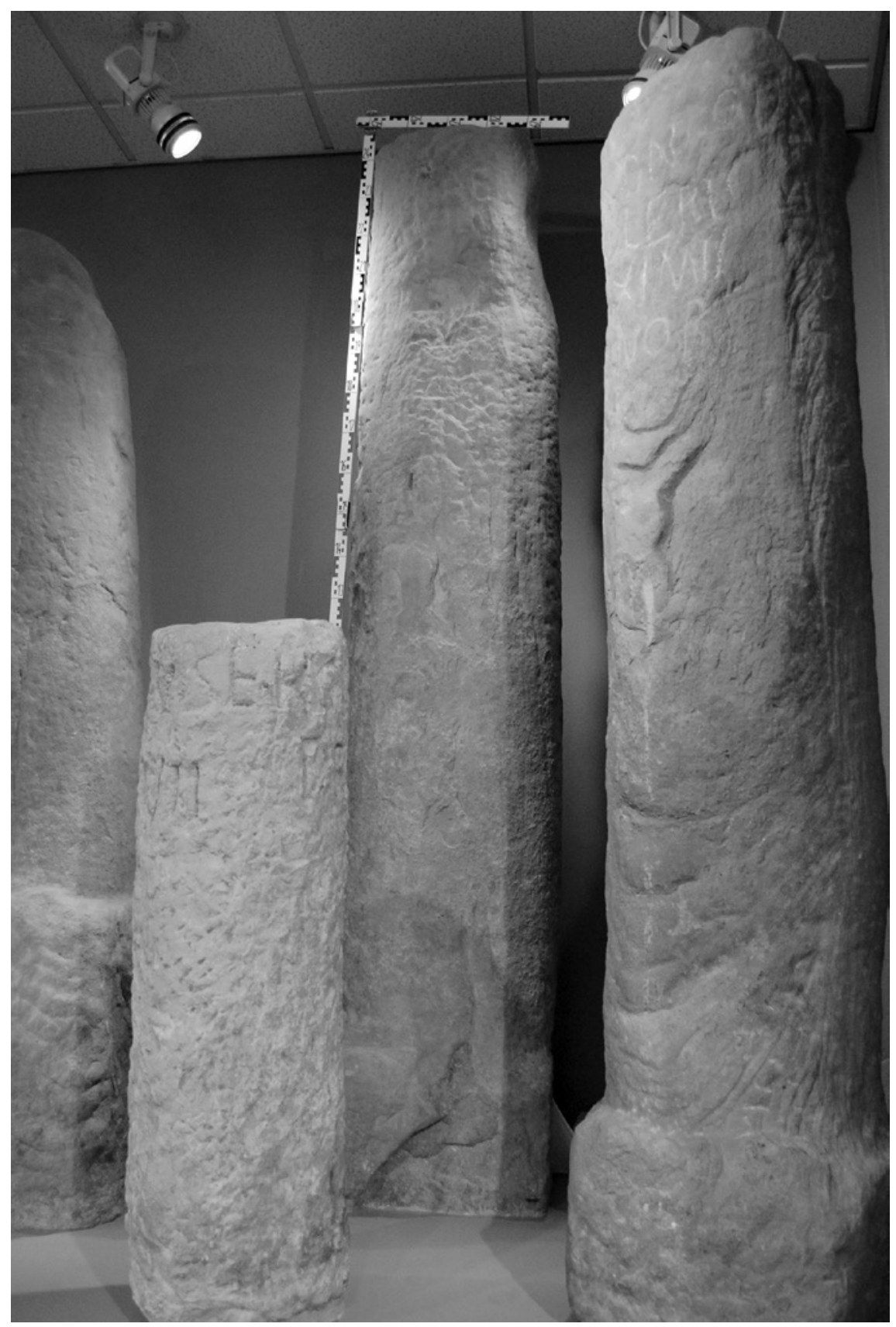

FIGURE 6.1 Republican and imperial milestones compared PHOTOGRAPH C. CAMPEDELLI (BBAW, BERLIN) 
Roads were here equipped with milestones from the year $3 / 2$ BCE. ${ }^{51}$ The main routes are the via from Bracara Augusta to Aquae Flaviae and Asturica, the via Bracara Augusta-Lucus Augusti-Asturica, the via nova Bracara-Asturica, built during the Flavian age, which run through the interior of the plunging cliffs of the conventus Bracaraugustanus, the conventus Asturum, and the extremely steep orographic conditions. The road was essential at a time of flourishing gold mining activities which, after initial developments under the Flavians, required increased infrastructure suitable for large-scale extraction and transport of the golden metal. Finally, milestones were also added to the coastal road from Bracara Augusta to Brigantium. In the praefecturae of Asturia and Callaecia the milestones are extremely plentiful. Between Braga and Astorga, along the province of Orensis, 281 milestones are attested. This follow, ranked in importance, the street from Bracara Augusta to Brigantium with 105 milestones (of which the great majority of discoveries were made between Bracara Augusta and Aquis Celenis). Between Bracara and Asturica through Aquae Flaviae 8 o milestones have been found.$^{52}$ One of the main features of the milestones in this region is, as can still be seen today, that they were often grouped into clusters placed side by side mentioning successive emperors (fig. 6.2). The monumentalisation of these road sectors is certainly shaped by the honorary

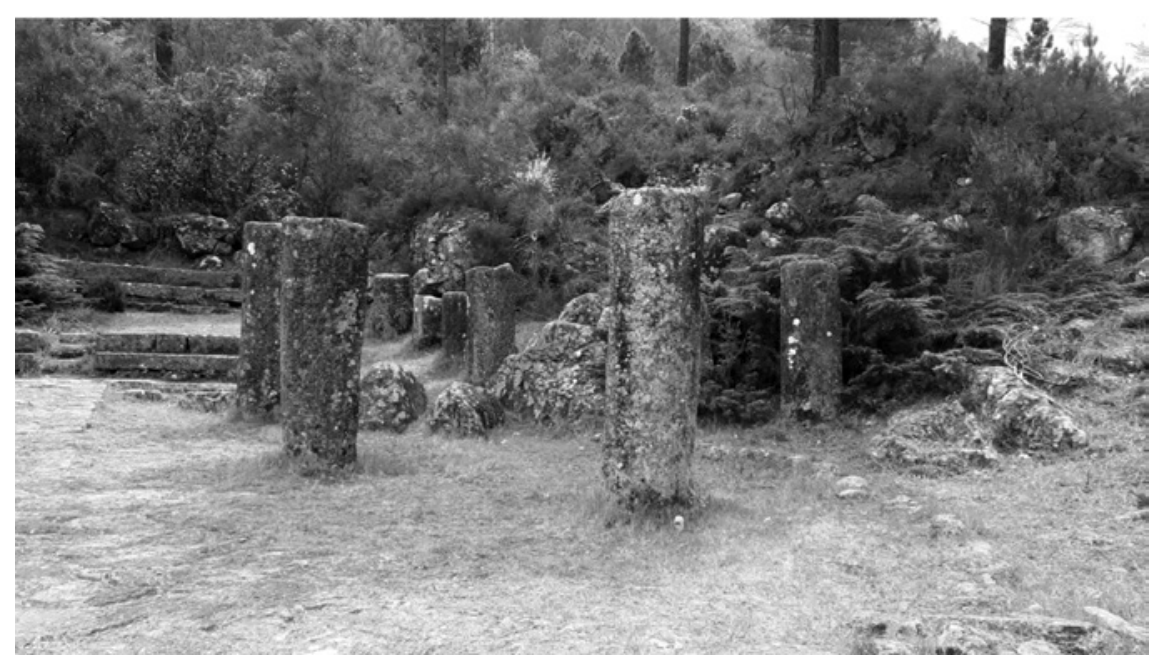

FIGURE 6.2 Cluster of milestones in Portela do Home COURTESY J.M. ABASCAL PALAZÓN

$5^{1} \quad$ Campedelli 2012, op. cit. (n. 46), 91.

$5^{2}$ Rodríguez Colmenero et al. 2004, op. cit. (n. 17) passim. 
function of the milestones from the 3rd century onwards, but also by the conformation of the surrounding environment, which required more frequent maintenance than those stretches on the plain.

\section{3}

\section{Conclusions}

From this study, although limited to the analysis of a few examples, it emerges that in the Iberian Peninsula, the building of roads developed on a pre-existing axial system that was adapted to the environment. Archaeological and epigraphic sources from Roman times attest that, in some cases, the terrain was modified to facilitate the passage and use of the routes. These changes certainly did not radically alter the physical landscape of the peninsula.

Nevertheless, the pre-existing tracks were formalised into Roman roads, especially from the time of Augustus onward, by erecting milestones inscribed with the name of the current emperor and by measuring distance in Roman miles. Thus, the Romanisation of its roads effected the Romanisation of the Iberian landscape. R.E. Witcher suggests that "the adoption of pre-existing routes was part of a far more subtle exercise of power offering to Rome considerable control over local populations." ${ }^{53}$ This also applies to the Iberian Peninsula, even if this phenomenon seems more a practical rather than an ideological plan.

Elsewhere, especially in Italy, but also in other provinces of the empire, the drilling and lowering of mountains was undertaken, as well as the construction of tunnels and terraces up to hundreds of meters deep, to make new roads passable. ${ }^{54}$ Consider the example of the removal of an entire hill of rock, executed under Trajan in Tarracina, to allow the rapid passage of the via Appia, or that of the building of a bridge and shipping-canal at the Iron Gates on the Danube. ${ }^{55}$ Certainly the morphological conformation of the Italian peninsula, garnished to the north by the Alpine chain and crossed by the Apennines along its longitudinal axis, made such works more necessary than in the case of the Iberian Peninsula. The via Amerina (from Rome to Ameria) differs in the nature of its construction north and south of Nepi. To the south, the road follows the contours of the landscape, rationalising the line of a pre-existing route. North of Nepi, the road, built some 15 o years later, is quite different. Not only does it cut across contours with an impressive straightness but also it comprises a wider

53 Witcher 1998, op. cit. (n. 8), 65 .

54 Coralini 1997 , op. cit. (n. 36), 279-335.

55 Coralini 1997, op. cit. (n. 36), 312-317. 
carriageway and a large masonry bridge. ${ }^{56}$ R.E. Witcher believes, in my opinion too speculatively, that this difference would not depend only on the fact that the two sections were built in different periods, the first on pre-existing routes, the second not, but also that "there was a conscious decision to build a very different type of road [...] the use of straight sections simplified the surveying of roads is not in dispute [and] the very need to survey in the first place can be read as an expression of the ideology of imperium."57

Political and administrative factors, in addition to the widespread use of sea links, must, in my opinion, be taken into account to explain the poor state of road works that radically changed the landscape in the Iberian peninsula, namely: 1st. After the final conquest by Augustus, the Hispania Romana became a provincia pacata, far from the 'hot' regions, i.e. the limes and the eastern provinces. For this reason, it was perhaps less necessary than elsewhere to build very fast connections. 2nd. The engineering works present in Italy, in addition to being complex to build, required constant maintenance. The responsibility for the maintenance of the roads (municipal or "Reichsstraßen") fell mainly on the inhabitants of the cities (cives, incolae and contributi) who, in the Iberian Peninsula, were certainly fewer in number than in Italy.58

If on the Iberian Peninsula the physical nature of the landscape did not undergo considerable changes, it is clear that the presence and use of roads with milestones constituted a radical change in the landscape, not so much in the passage from the pre-Roman phase to the Roman one, but in the transition from the Republic to the Empire when, as already demonstrated, a few streets with small columns bearing the name of the proconsul were replaced by imposing milestones and clusters of milestones, bridges and arches. ${ }^{59}$ The indigenous population which used paved roads bearing the name of the emperor (e.g., via Augusta), stone bridges (e.g., the bridge of las Alcantarillas), ${ }^{60}$ and milestones to calculate distances in miles therefore participated in the ideology of imperium through their engagement with these practical and tangible expressions of Roman dominion.

$5^{6} \quad$ M.W. Frederiksen and J.B. Ward Perkins, 'The ancient road systems of the central and northern Ager Faliscus (Notes on Southern Etruria, 2)', PBSR 25 (1957), 90.

57 Witcher 1998, op. cit. (n. 8), 62-64.

58 For Italy see W. Eck, L'Italia nell'impero romano: stato e amministrazione in epoca imperiale (Bari 1999), 76-8o; C. Campedelli, L'amministrazione municipale delle strade romane in Italia (Bonn 2014).

59 Campedelli 2012, op. cit. (n. 46), 92.

6o C. Campedelli, 'Nuova lettura delle iscrizioni del ponte di Las Alcantarillas (Siviglia)', Epigraphica 79 (2017), 488-492. 
It is therefore through the monumentalisation of the roads, through the positioning of arches in the most strategic points, through the construction of stone bridges, and above all, through the erection of milestones, due to which an accurate measurement and therefore perception of the territory was made possible, that the Iberian landscape was transformed into a Roman landscape. 